\title{
Dilation of epidural space and posterior soft tissue veins in Hirayama disease
}

\author{
Jean-Baptiste Chanson, 1,2 Mathilde Renaud, ${ }^{1}$ Andoni Echaniz-Laguna, 1,2 \\ Meriam Koob ${ }^{3}$
}

'Département de Neurologie, Hopitaux universitaires de Strasbourg, Strasbourg, France ${ }^{2}$ Centre de Référence Neuromusculaire du Grand Est, Hopitaux universitaires de Strasbourg, Strasbourg, Alsace, France

${ }^{3}$ Département de Radiologie, Hopitaux universitaires de Strasbourg, Strasbourg, France

\section{Correspondence to}

Dr Jean-Baptiste Chanson, jean-baptiste.chanson@chrustrasbourg.fr,

jb.chanson@hotmail.fr

Accepted 18 August 2017

\begin{tabular}{|l|}
\hline To cite: Chanson J-B, \\
Renaud M, Echaniz-Laguna A, \\
et al. BMJ Case Rep \\
Published Online First: \\
[please include Day Month \\
Year]. doi:10.1136/bcr-2017- \\
220787
\end{tabular}

To cite: Chanson J-B, Renaud M, Echaniz-Laguna A, et al. BMJ Case Rep Published Online First: please include Day Month
Yearl. doi:10.1136/bcr-2017 220787

\section{DESCRIPTION}

An 18-year-old man presented with distal weakness and amyotrophy of the right hand for a few months. He had no familial or personal medical history. Clinical examination showed atrophy and a marked weakness of right hypothenar and interossei muscles (grade 1/5 on Medical Research Council scale) and a mild weakness of right thumb abduction and wrist extension (4/5). Biceps, brachioradial and triceps tendon reflexes were normal and symmetric. There were no fasciculation, sensory abnormality or pain. Motor nerve conduction studies showed a reduced amplitude of compound muscle action potential of the right ulnar nerve but normal parameters of left ulnar and two median nerves. No focal slowing or conduction block was found. Studies of bilateral median, ulnar and right medial antebrachial cutaneous sensory nerves were normal. Electromyographic examination found active denervation (fibrillation potentials and neurogenic recruitment) in right C8-T1 innervated muscles (abductor pollicis brevis, first dorsal interosseus, extensor indicis proprius, C8 innervated paraspinal muscle) and mild chronic denervation (neurogenic recruitment) in asymptomatic left C8-T1 innervated muscles (abductor pollicis brevis and first dorsal interosseus). Other muscles in upper and lower limbs and those innervated by bulbar nerves were normal. Routine blood analyses, Lyme, HIV and hepatitis $C$ virus serologies and antinuclear and anti-GM1 antibodies as well as cerebrospinal fluid analysis were normal. A cervical MRI performed in neutral position revealed no radiculopathy or myelopathy but a clear dilation of posterior soft tissues veins on T1-weighted sequences with gadolinium infusion (figure 1). In flexion position, a forward displacement of dural sac was detected (figure 1).

Hirayama disease (HD) was therefore diagnosed because of the association of MRI findings and typical demographic, clinical and electrophysiological characteristics ${ }^{1}$ and the lack of elements for another disease. No surgery was performed. After 2 years of follow-up, clinical signs remained stable, thus confirming the HD diagnosis.

$\mathrm{HD}$ is a rare but disabling disease of cervical spinal cord resulting in unilateral or asymmetric severe amyotrophy and weakness of distal arms in young male patients. ${ }^{1}$ Differential diagnosis with amyotrophic lateral sclerosis and other disorders is important to estimate correctly the prognosis and to discuss specific therapy. ${ }^{2}$

HD diagnosis is difficult because it is based on the demonstration of a forward displacement of

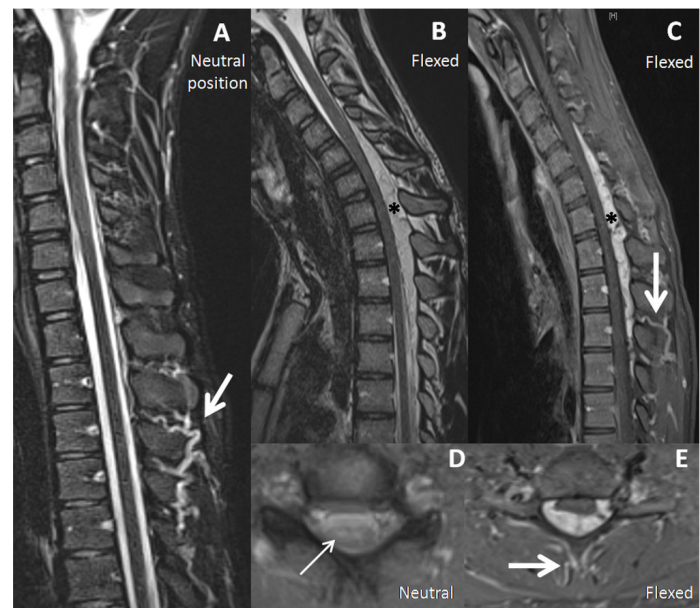

Figure 1 Venous dilation on cervical MRI of a patient with Hirayama disease. Marked dilation of posterior soft tissue veins (thick arrows) detectable in neutral $(A)$ and flexion position $(C, E)$; the crescent-shaped dilation of the epidural venous plexus (asterisks) was detectable only in flexion position ( $B, C)$; snake-eyes sign (thin arrow) (D) ( $A, B$ and $D: T 2$ sequences; $C$ and $E:$ contrast-enhanced $T 1$ sequences).

dural sac on cervical MRI in flexion position. Such sequences are performed only if HD diagnosis has been considered before MRI. Posterior venous dilation is a less known radiological sign of HD. It might be related to reduced venous blood flow in HD. ${ }^{3}$ It was previously reported only in flexed position. ${ }^{12}$ Our case shows that it can be observed also in neutral position. This finding may help to suggest HD diagnosis in classical sequences. The diagnosis will be thereafter confirmed by MRI in flexion position.

\section{Learning points}

- The diagnosis of Hirayama disease is classically based on forward displacement of spinal cord on MRI, which is detectable only in flexion position.

- Another abnormality suggestive of Hirayama disease is the dilation of posterior soft tissue veins.

- This sign is especially interesting because it may be detected in standard position, as showed by our case. 
Acknowledgements The authors thank Professor Jean-Louis Dietemann (Service de radiologie, Hopitaux universitaires de Strasbourg) for his valuable help and comments.

Contributors JBC: gathering of data and drafting of the manuscript; MR: gathering of data and revision of the manuscript; MK: gathering of data and revision of the manuscript; AEL: gathering of data and revision of the manuscript.

Competing interests None declared.

Patient consent Obtained.

Provenance and peer review Not commissioned; externally peer reviewed. (c) BMJ Publishing Group Ltd (unless otherwise stated in the text of the article) 2017. All rights reserved. No commercial use is permitted unless otherwise expressly granted.

\section{REFERENCES}

1 Hirayama K. Juvenile muscular atrophy of distal upper extremity (Hirayama disease). Intern Med 2000;39:283-90.

2 Cortese R, Gerevini S, Dicuonzo F, et al. Hirayama disease: the importance of an early diagnosis. Neurol Sci 2015;36:1049-50.

3 Baba Y, Nakajima M, Utsunomiya $H$, et al. Magnetic resonance imaging of thoracic epidural venous dilation in Hirayama disease. Neurology 2004;62:1426-8.

Copyright 2017 BMJ Publishing Group. All rights reserved. For permission to reuse any of this content visit

http://group.bmj.com/group/rights-licensing/permissions.

BMJ Case Report Fellows may re-use this article for personal use and teaching without any further permission.

Become a Fellow of BMJ Case Reports today and you can:

- Submit as many cases as you like

- Enjoy fast sympathetic peer review and rapid publication of accepted articles

- Access all the published articles

- Re-use any of the published material for personal use and teaching without further permission

For information on Institutional Fellowships contact consortiasales@bmjgroup.com

Visit casereports.bmj.com for more articles like this and to become a Fellow 